\title{
Risk-taking behaviour of family firms: evidence from Tunisia
}

\section{Dorra Ellouze*}

Univ. Manouba, Ecole Supérieure de Commerce de Tunis, RIM RAF UR13ES56, Campus Universitaire Manouba, 2010, Tunisia

Email: doellouze@gmail.com

*Corresponding author

\section{Khadija Mnasri}

\author{
RIM RAF UR13ES56 (ESCT), \\ Institut Supérieur de Gestion de Tunis, \\ 41, Avenue de la Liberté, Cité Bouchoucha, \\ Le Bardo 2000, Tunisia \\ Email: khadija.mnasri@gmail.com
}

\begin{abstract}
Using a unique database of 87 Tunisian non-financial firms over the period 1998-2014, we analyse risk-taking behaviour of family firms. We find evidence that family ownership is positively related to corporate risk-taking. But family firms undertake less risky projects when the manager is not a member of the family or when the founder is no longer active in the firm. Our results show also that in these cases, family ownership becomes negatively associated to risk-taking. Finally, we find that family firms take more risk only when they belong to diversified groups, especially those operating in several industries.
\end{abstract}

Keywords: family ownership; corporate governance; group affiliation; risk-taking.

Reference to this paper should be made as follows: Ellouze, D. and Mnasri, K. (2020) 'Risk-taking behaviour of family firms: evidence from Tunisia', Int. J. Entrepreneurship and Small Business, Vol. 39, Nos. 1/2, pp.192-221.

Biographical notes: Dorra Ellouze is an Assistant Professor at the Tunis High Business School of the University of Manouba, Tunisia. She holds a PhD in Finance from the faculty of Economics and Management Sciences, University Tunis El Manar, Tunisia. Her teaching interests are in corporate finance and accounting. Her main research interests include corporate governance, corporate social responsibility, investment and financing decisions and risk-taking.

Khadija Mnasri is an Assistant Professor at the High Institute of Management, University of Tunis, Tunisia. She holds a PhD in Finance from the Faculty of Economics and Management Sciences, University Tunis El Manar, Tunisia. Her teaching interests are in corporate finance and corporate governance. Her main research interests include corporate governance, corporate finance and financial markets. 


\section{Introduction}

Family business plays an important role in the economy, especially in emerging markets where this type of firms is prevalent. In Tunisia, the overwhelming majority of small and medium enterprises are family-owned. Also, a significant proportion of large firms are family controlled. According to the annual ranking of Tunisian companies provided by 'L'Economiste Maghrébin' in January 2016, 110 among the 200 largest firms are controlled by families. Moreover, among the 79 firms listed in the Tunisian stock exchange in 2016, 42 are family controlled.

A large body of literature predicts that family firms outperform non-family ones. In fact, the ownership structure in family controlled firms ensures an effective alignment of interests between owners and managers (Jensen and Meckling, 1976). Moreover, families seek the continuity of their business and have often a longer-term orientation. They are also motivated to adopt innovative investments and promote entrepreneurship (Zahra, 2005).

Several researchers have been interested about family firms in Tunisia. They show that these firms are productive and able to create value for the long term (Gherib and Souissi, 2004; Masmoudi and Gherib, 2004; Zaddem, 2007; Madani, 2010; Benmostefa, 2015; Mnasri and Ellouze, 2015). However, none of these studies have analysed the risk-taking behaviour of family firms in Tunisia. Yet, it is expected that profitability and effectiveness of these firms comes from their willingness to undertake risky, innovative and value enhancing investment projects.

The empirical evidence focusing on the effect of family ownership on firms' risk-taking in other contexts is not conclusive. On the one hand, a set of empirical studies shows that family firms are risk-averse because shareholders often stake their entire human and financial capital on their firms (Mishra and McConaughy, 1999; McConaughy et al., 2001; Anderson et al., 2003; Choi et al., 2015). On the other hand, another set of papers content that family-firms are more long term oriented and invest more in risky projects such as R\&D and innovative investments. Indeed, they are assumed to undergo lower agency conflicts between managers and shareholders (Zahra, 2005; Nguyen, 2011; Schmid et al., 2014). Furthermore, these firms accept to take a significant level of risk in order to avoid losing their socio-emotional wealth such as reputation, social status and family dynasty (Gómez-Mejía et al., 2007). Thus, in this paper, we propose to test the impact of family ownership on corporate risk-taking in Tunisia.

When we closely analyse the shareholding structure and governance of these firms, we realise that a lot of them belong to groups, especially large ones. In fact, in 2016, 34 groups among the 40 largest ones in Tunisia are controlled by families ('L'Economiste Maghrébin, 2016'). These large groups are often well-diversified conglomerates with pyramidal structure and cross-holdings and where a family or a group of families monopolise the majority of shares.

The advantage of forming groups in emerging markets is to overcome problems of lack of information transparency, inefficiencies of legal system and imperfections in capital, labour and product markets. Indeed, business groups act as 'functional market substitutes' providing stability, financing, partnerships and economies of scale and scope (Guillen, 2000; Shyu, 2013; Bamiatzi et al., 2014; Ratten et al., 2017). Therefore, our 
analysis of risk-taking in family firms should take into account the special feature of the affiliation of these firms to groups.

The financial literature widely supports the idea that firms affiliated to a group undertake more risky projects than stand-alone ones. On the one hand, business groups offer technological linkages, know-how and innovative infrastructures, which leads to uncertainty and more risk-taking (Kim and Lui, 2015). On the other hand, diversification inside the groups encourages shareholders to take more risk because their wealth is spread over several companies operating in different industries (Paligorova, 2010; Faccio et al., 2011). Hence, in this paper, we examine whether risk-taking behaviour of Tunisian family firms may be affected by their affiliation to a group and by the degree of the diversification inside their groups.

Another stream of research focuses on the effect of governance characteristics in family firms such as family management and the active role of the founder. The agency perspective suggests that conflicts of interests between owners and managers are mitigated when the manager is a member of the founding family, which leads family firms to undertake more value creating research and development projects in this case (Zahra, 2005). Moreover, the stewardship theory contents that owners-managers seek the general interest of the firm in order to maintain their socio-emotional needs (Cabrera-Suárez and Santana-Martín, 2015).

The active role played by the founder is also an important feature that has been investigated in the corporate governance literature. Most empirical studies examining this feature predict that risk-taking in family firms is higher when the founder is still active in the firm. Indeed, members of the family of later generations have fewer emotional ties to the business and may lack experience, know-how and competence to adequately manage the firm. However, founders are more attached to their firms and are able to undertake more value enhancing risky projects. Then, we propose also to investigate whether risk-taking behaviour of family firms depends on these corporate governance characteristics.

To conduct our study, we have collected detailed information for 87 non-financial Tunisian firms making public offerings over the period 1998-2014. To deal with problems of endogeneity, we consider dynamic models using the Blundell and Bond (1998) GMM estimator.

Our paper contributes to the existing literature in several ways. First, while the majority of studies in the Tunisian context emphasise the performance of family firms, our study investigates the risk-taking behaviour of this type of firms. Second, we focus on the special feature of the affiliation of family firms to groups. To our knowledge, this is the first study that examines how group affiliation and diversification inside groups conditions risk-taking of family firms. Finally, we contribute to the literature on corporate governance characteristics of family firms by documenting how risk-taking behaviour may change when the founder is no longer active in the firm or the manager is not a member of the family. To the best of our knowledge, the combined effect of group affiliation and governance characteristics in family firms has not been previously examined in any context.

The reminder of this paper is organised as follows. Section 2 provides a literature review and develops the hypotheses. In section 3, we describe the sample and variables. Section 4 presents descriptive statistics and univariate analysis. Section 5 reports empirical results of the multivariate analysis. Section 6 provides a further analysis of the 
interaction between family ownership and firm characteristics. We also perform a set of robustness checks in Section 7. Section 8 summarises and concludes.

\section{Literature review and hypotheses development}

\subsection{Risk-taking in family firms}

Several finance literatures have studied costs and benefits of family firms and their corporate governance. There are two major effects of family ownership predicted by the literature. Many researchers are in favour of the entrenchment effect. They point out that family firms underperform compared to non-family ones because families use their power to extract private benefits on behalf of minority shareholders (Demsetz, 1983; Demsetz and Lehn, 1985; Claessens et al., 2002; Patel and Chrisman, 2013). However, several other studies support the incentive effect: they document that family firms are more profitable and better governed than non-family ones. Indeed, conflicts of interest between owners and managers are generally limited in family-controlled firms. In the same time, families seek to maintain their control for the long-term. They are motivated to make the decision process less bureaucratic and put in precious skills to the firm, which leads to a better performance (Barontini and Caprio, 2006; Miller et al., 2007; Erbetta et al., 2013).

Since there is a close relationship between performance and risk-taking, another stream of research focuses on risk-taking of family-firms. Several papers support the view that family-firms are risk-averse. This risk aversion can be explained by the fact that families often stake their entire human and financial capital on their firms (Shleifer and Vishny, 1986; Paligorova, 2010). Consequently, families seek to avoid risk-taking in order to maintain their control in their firms, preserve their wealth, reputation and social status and transfer the firm to the next generation (La Porta et al., 1999; Morck and Yeung, 2003).

Many empirical works show that family firms adopt a conservative orientation, limit growth rates and use less debt than their counterparts in order to avoid risk exposure (Mishra and McConaughy, 1999; McConaughy et al., 2001; Anderson et al., 2003). Other studies argue that family firms invest less in innovation and research and development activities. For example, using data on Korean firms over the period 1998-2007, Choi et al. (2015) document that family ownership is negatively associated to R\&D investments, and this relationship becomes positive only when growth opportunities are important.

In contrast, another set of studies content that family firms take more risk than other firms. They refer to the agency theory predicting that firms managed by controlling shareholders undertake more efficient investments because of the alignment of interests between managers and shareholders (Berle and Means, 1932; Jensen and Meckling, 1976).

Since family-owned firms are often managed by their founders or a member of the family, they are assumed to have lower agency conflicts and to be more long-term oriented. This conjecture suggests that family firms should invest more in risky projects, such as R\&D and innovation investments (Zahra, 2005; Nguyen, 2011; Schmid et al., 2014). The empirical study of Anderson and Reeb (2003) corroborates this contention. In fact, they find that compared to non-family firms, family ones experience less 
diversification but have comparable levels of debt and risk. They also demonstrate that family holdings are not limited to low risk businesses or industries and that minority shareholders in large US firms benefit from the presence of founding families.

Gómez-Mejía et al. (2007) offer another explanation to argue that family firms may not be risk averse. Referring to the behavioural theory, they suggest that family firms fear losing their socio-emotional wealth (such as identity, reputation, social status and family dynasty) and to avoid these losses, they accept to take a significant level of risk. The authors conduct an empirical study using a sample of 1,237 family owned olive mills in Southern Spain that have the opportunity to become a member of a cooperative. This opportunity leads to less risk exposure, more profits and loss of family control. The results show surprisingly that many families refuse to join a cooperative despite the advantage of reduced risk and higher gains. Gómez-Mejía et al. (2007) conclude that these families are willing to take more risk in order to maintain their control and socio-emotional wealth.

In Tunisia, it has been argued that family firms and particularly those in which founders are still active tend to be reluctant to open their capital to new shareholders because they seek the perpetuation of the family dynasty (Khanchel, 2007; Gharbi and Ben Ouda, 2011). They are also usually more profitable and more productive than their counterparts because family managers are more visionary and experienced. Mnasri and Ellouze (2015) show that family ownership is positively and significantly associated with firm productivity for a sample of Tunisian firms involved in public debt issuing during the period 1998-2012. They conclude that family firms implement survival strategies leading to productivity improvement.

Referring to the behavioural theory like Gómez-Mejía et al. (2007), we can expect that to avoid losing their socio-emotional wealth and to ensure better performance, family firms in Tunisia would undertake more risky projects than non-family ones. Thus, we posit:

Hypothesis 1 Family firms take more risk than non-family firms in Tunisia.

\subsection{Business group affiliation, diversification and risk-taking}

Business groups controlled by families are common around the world and particularly in emerging markets (Ratten et al., 2017). A business group is defined as a constellation of independent firms linked together through investment transfers and having common ownership and administrative control (Bamiatzi et al., 2014). In these groups, controlling owners maintain authority through pyramidal ownership structures and cross-holdings (Shyu, 2013; Byun et al., 2013).

In Tunisia, the number of business groups has significantly increased in recent years. According to the Tunisian Central Bank statistics, there are 2,429 groups in 2011 against only 942 groups in 1998 .

Several authors argue that group-affiliated firms play an important role in emerging markets where legal systems are immature, transparency and information disclosure are insufficient and capital markets are inefficient. They show that in developing countries, business groups act as 'functional market substitutes' providing stability and helping firms to overcome inefficiency in external capital markets (Guillen, 2000; Shyu, 2013; Bamiatzi et al., 2014). 
A large number of empirical studies document that group affiliated firms outperform stand-alone ones (Chang and Choi, 1988; Perotti and Gelfer, 2001; Khanna and Palepu, 2000a, 2000b). For example, Lensink and Molen (2010) show that in India, group affiliation not only generates higher market valuation, but also reduces financial constraints.

Since it is argued that to achieve better performance, firms seek to undertake value-enhancing risky projects, we expect that group-affiliated firms would follow more risky investment policy (John et al., 2008).

Another argument in favour of a positive relationship between group affiliation and risk-taking is the role of this organisational structure in enhancing innovation. In fact, in emerging economies, where innovation is costly and not well supported, business groups afford innovation infrastructures: they provide their affiliates low-cost financial resources, offer them more technological linkages and know-how and develop an internal market for innovation outputs (Kim and Lui, 2015). When innovation is enhanced, uncertainty rises which leads to more risk-taking in group-affiliated firms.

Furthermore, shareholders of firms belonging to a group are well diversified because their wealth is spread over several companies operating most likely in different industries. This diversification will foster corporate risk-taking in group-affiliated firms (Paligorova, 2010).

Faccio et al. (2011) investigate the relation between owners' portfolio diversification and corporate risk-taking. They find strong statistical evidence that well-diversified large shareholders undertake riskier investments than non-diversified ones.

Based on this discussion, we hypothesise that:

Hypothesis 2 Family firms affiliated to a group undertake more risky projects than stand-alone ones.

Khanna and Palepu (2000b) note that the internal structure of business groups differ from one group to another. They posit that group affiliation is beneficial only if the degree of diversification is greater than a certain threshold.

Similarly, Faccio et al. (2011) find that an increase in the level of portfolio diversification from the first to the third quartile of the distribution leads to a substantial increase in risk-taking.

According to these results, we posit:

Hypothesis 3 Group affiliated family firms undertake more risky projects when they are more diversified.

\subsection{Family firm characteristics and risk-taking}

Risk-taking in family firms may be affected by firm characteristics such as family management or the active role played by the founder of the firm.

\subsubsection{Family management}

Strategic investment decisions of family firms depend on the involvement of family members in the firm's management. Building on agency and stewardship theories, several empirical studies suggest that family firms are more profitable and willing to 
undertake more value creating research and development projects when the CEO is a member of the family (Gordini, 2016).

On the one hand, the agency perspective predicts that conflicts of interest between owners and managers from the same family are often mitigated. This situation ensures effective decision making perpetuating the continuity of the firm (Jensen and Meckling, 1976). Agency theorists also content that owners-managers are visionary and usually empowered to make key decisions with an eye on the long term, which leads to maximising their families' wealth (Zahra, 2005).

On the other hand, the stewardship theory posits that managers' behaviour may be motivated by the general interests of the firm and not their own private interests. Consequently, owners-managers of family firms often use their firms as vehicles for sustaining the family's trans-generational economic and socio-emotional needs (Cabrera-Suárez and Santana-Martín, 2015).

Moreover, a familial CEO is prone to behave altruistically making more risky decisions that increase family wealth and firm value (González-Cruz and Cruz-Ros, 2016).

These CEOs, and members of the family, are then expected to invest in value enhancing projects, pursue promising entrepreneurial opportunities and support radical innovations that enhance organisational growth (Zahra, 2005).

Following prior literature, we propose that:

Hypothesis 4 Family management has a positive impact on risk-taking in family controlled firms.

\subsubsection{The active role of the founder}

Previous literature argues that family succession is an important issue that may negatively impact firm value and investment choices. Zahra (2005) note that founders are often more innovative than other managers following them in leading the organisation. Anderson and Reeb (2003) show that compared to their descendants, founders tend to have greater amount of emotional investment in the business, resulting in long-term investment horizons for the firm.

Most empirical studies examining the relationship between the presence of founding family and firm performance conclude that family ownership creates value only when the founder is still active in the firm, either as a CEO or a chairman with a hired CEO (Villalonga and Amit, 2006; Muttakin et al., 2014). Using panel data on 275 German exchange-listed companies, Andres (2008) points out that the performance of family businesses is only better when the founding family is still active either on the executive or the supervisory board. He shows also that if families are just large shareholders without board representation, the performance of their companies is not distinguishable from other firms.

These results are explained by the fact that family members of the second and later generations have fewer emotional ties to the business and may lack the necessary skills and competences to adequately manage the firms (Villalonga and Amit, 2006; González-Cruz and Cruz-Ros, 2016).

Moreover, because of disparity of interests between family members, agency problems and conflicts are often higher when the number of generations increases in the firm. Using family firm-level Canadian data, Morck et al. (2000) document that 
heir-controlled Canadian firms show low industry-adjusted financial performance, labour capital ratios and $R \& D$ spending relative to other firms with the same ages and sizes. However, firms controlled by their founders are more profitable and grow more rapidly than other firms.

As a result, when the founder is still active in the firm, family firms are expected to pursue more risky investment policies in order to promote efficient investments and innovation. These founders have often a superior technological knowledge which is not necessarily the case of their descendants (Schmid et al., 2014).

Building on the above discussion, we propose the following hypotheses:

Hypothesis 5 Risk-taking in family firms is higher when the founder is still active in the firm.

Hypothesis 6 Family succession to the next generation has a negative impact on risk-taking.

\section{Sample and variables}

\subsection{Sample}

Tunisia is an ideal context for testing our hypotheses since family firms and business groups are very common and large diversified groups are most likely controlled by families. Indeed, according to the annual ranking of Tunisian companies provided by 'L'Economiste Maghrébin' in January 2016, 110 among the 200 largest companies are family-owned. Moreover, among the 40 largest groups, 34 are controlled by families.

In this study, we focus on large non-financial companies making public offerings (either listed firms or firms involved in public debt issuing) from 1998 to 2014. Our sample includes 87 firms. In total, 44 of these firms are listed in Tunis stock exchange, BVMT. ${ }^{1}$

All firms of our sample are large and active in several industries (chemical industry, industrial goods and services, construction and materials, food and beverage, telecommunication and technology, hotels and restaurants, consumer services and transportation). Referring to the 2016 ranking of 'L'Econmiste Maghrébin', 57 firms in our sample are among the 500 largest companies. Table 1 panel A presents the number and the proportion of firms belonging to each specific industry according to the BVMT classification.

In our sample, 69 among 87 firms are family-controlled and 60 firms belong to a business group. ${ }^{2}$ Among the 69 family firms, 55 are group-affiliated (See Panel B of Table 1).

In the sub-sample of family firms, families hold on average $60 \%$ of the equity stakes denoting the high ownership concentration in the hands of families. Furthermore, about $70 \%$ of these firms are managed by a member of the family and in $62 \%$ of them, the founder in still active (either as executive officer or chairman of the board of directors). On the other hand, only $9 \%$ of these family firms are owned by the descendants of the founder (i.e., there has been a succession of the ownership to the next generation).

Panel $\mathrm{C}$ of Table 1 shows that in our sample, affiliated firms (60 firms) belong to diversified groups. In fact, the average number of firms in these groups is about 18 with a minimum of two companies and a maximum of 117 companies. Moreover, there is on 
average 7.42 industries in each group with a minimum of one industry and a maximum of 22 industries in the same group (according to the classification of the National Institute of Statistics (NIS) considering 30 industries in total). In the Appendix A, we present the classification of industries referring to the NIS.

Table 1 Sample description

\begin{tabular}{lcc}
\hline \multicolumn{3}{c}{ Panel A: number of firms by industry } \\
\hline Industry & Number & Percentage \\
\hline Chemical industry & 6 & $6.9 \%$ \\
Consumer services & 10 & $11.49 \%$ \\
Industrial goods and services & 17 & $19.54 \%$ \\
Construction and materials & 10 & $11.49 \%$ \\
Food and beverage & 14 & $16.09 \%$ \\
Telecommunication and technology & 8 & $9.2 \%$ \\
Transportation & 6 & $6.9 \%$ \\
Hotels and restaurants & 16 & $18.39 \%$ \\
\hline
\end{tabular}

Panel B: number of family and group affiliated firms

\begin{tabular}{|c|c|c|c|c|c|c|}
\hline \multicolumn{7}{|c|}{ Total sample: 87 non-financial firms } \\
\hline \multicolumn{3}{|l|}{ Family firms } & \multicolumn{4}{|c|}{ Non-family firms } \\
\hline \multicolumn{3}{|l|}{69} & \multicolumn{4}{|c|}{18} \\
\hline Group affiliated & \multicolumn{2}{|c|}{ Non-affiliated } & \multicolumn{2}{|c|}{ Group affiliated } & \multicolumn{2}{|c|}{ Non-affiliated } \\
\hline 55 & \multicolumn{2}{|c|}{14} & \multicolumn{2}{|r|}{5} & \multicolumn{2}{|r|}{13} \\
\hline \multicolumn{7}{|c|}{ Panel C: diversification of group-affiliated firms } \\
\hline \multicolumn{7}{|c|}{ Sample of group-affiliated firms: 60 non-financial firms } \\
\hline & & Mean & Median & $\begin{array}{l}\text { Standard } \\
\text { deviation }\end{array}$ & Minimum & Maximum \\
\hline Number of firms & up & 17.93 & 15 & 15.57 & 2 & 117 \\
\hline Number of indus & y group & 7.43 & 8 & 4.47 & 1 & 22 \\
\hline
\end{tabular}

Notes: This table reports in panels A and B the distribution of the sample of 87 non-financial Tunisian firms by industry, type (family, and non-family) and affiliation (group affiliated, and stand-alone). Panel C presents summary statistics referring to the diversification of group affiliated firms.

Consequently, our descriptive statistics show that groups of our sample are well diversified, which is not the case of the whole population of Tunisian groups. Indeed, according to the Central Bank statistics of 2011, 90\% of groups include between two and five companies and only $3.5 \%$ of them are composed of more than ten companies. Referring to the same statistics, the average number of firms per group is 3.8.

\subsection{Variables}

In this subsection, we present the variables used in the different models estimated in this study. These variables are also described in detail in the Appendix B. 


\subsubsection{Risk-taking}

Our primary measure of corporate risk-taking is the performance volatility. Following previous studies (e.g., John et al., 2008; Paligorova, 2010; Faccio et al., 2011; Boubakri et al., 2013), we measure earnings volatility in four-year overlapping periods. ${ }^{3}$

$$
\text { Risk }=\sqrt{\frac{1}{T-1} \sum_{t=1}^{T}\left(E_{i t}-\frac{1}{T} \sum E_{i t}\right)^{2}} / T=4 .
$$

We consider two variables of risk-taking: Risk1 and Risk2.

- $\quad$ For Risk1, $E_{i t}=\frac{E B I T D A}{\text { Total Assets }}$

- $\quad$ For Risk2, $E_{i t}=\frac{E B I T}{\text { Total Assets }}$

To construct these variables, data are hand collected from the financial statements provided by the Financial Market Council and the Stock Exchange of Tunis.

\subsubsection{Family ownership}

To investigate the impact of family ownership on risk-taking, we define the two following variables:

- Family: the percentage of ownership stakes belonging to the family.

We consider all stakes hold by other entities having a special relationship with the principal family shareholder, especially other family members and affiliated firms. In fact, Choi et al. (2015) content that affiliates' ownership must be included in family ownership since affiliates in the Korean context are owned and controlled by the business group of the family. This is also the case of the Tunisian context where the pyramidal structure of groups complicates the ownership network. To measure family ownership, we hand collect data on ownership structure of firms from prospectus, activity reports and documents available in the Financial Market Council.

- D-family: a dummy variable that equals one if the ownership stake belonging to family members exceeds $5 \%$ and zero otherwise.

We refer to Choi et al. (2015) specifying that family firms are those where the controlling owner and/or his or her family holds $5 \%$ or more of the firm's equity and at least one of them is the CEO, president, chairman, vice-president or a board member.

\subsubsection{Group affiliation}

To distinguish firms according to their affiliation to a group, we construct a dummy variable: 
- Group: equals one if the firm is a member of a business group and zero otherwise.

Following Paligorova (2010), we use two measures of diversification inside the group:

$1 \mathrm{Nb}-F G$ : the natural logarithm of the number of firms in the group.

$2 \mathrm{Nb}-I G$ : the natural logarithm of the number of industries in which the group operates.

To construct these variables, we have collected data for each group and each year about the number of firms in the group and their specific industries. We consider the classification of the NIS which is more detailed than the BVMT classification and based on 30 industries (see Appendix A).

Our data sources are company websites and some prospectus available in the Financial Market Council.

\subsubsection{Family firm characteristics}

To analyse the influence of corporate governance characteristics of family firms, we also hand collected detailed data on board structures to construct variables related to the founders and their families. Our sources are company websites, documents of the Financial Market Council and the Stock Exchange of Tunis and public information. To know if the manager or the supervisor is founder, descendent, member of the family or not, we made cross-checking using several publicly available documents.

Note that all the firms of our sample follow the monist structure, i.e., they have a unitary board ${ }^{4}$ and for the majority of these firms, there is a CEO duality.

Referring to Schmid et al. (2014), we use the following variables:

- Fam.manag: is a dummy variable that equals one if the CEO or the executive officer is a member of the family and zero otherwise.

- Found.manag: is a dummy variable that equals one if the CEO or the executive officer is the founder and zero otherwise.

- Latergen.manag: is a dummy variable that equals one if a descendant of the founder is the CEO or the executive officer and zero otherwise.

- Found.sup: is a dummy variable that equals one if the founder is the chairman of the board of directors and zero otherwise.

- Latergen.sup: is a dummy variable that equals one if the chairman of the board of directors is one of the descendants of the founder and zero otherwise.

- Succession: is a dummy variable that equals one if there has been a succession of the ownership to the descendants of the founder.

\subsubsection{Control variables}

In our models, we include standard control variables that could be associated to risk-taking. Referring to John et al. (2008), Boubakri et al. (2013), Schmid et al. (2014) and Choi et al. (2015) among others, we consider: 
- Lnassets: a variable proxy of firm size measured by the natural logarithm of total assets

- Leverage: the debt to assets ratio: $\frac{\text { Total liabilities }}{\text { Total Assets }}$

- Profitability: measured by the ratio $\frac{E B I T D A}{\text { Assets }}$.

- Age: the firm age measured by the natural logarithm of the number of years since firm's incorporation.

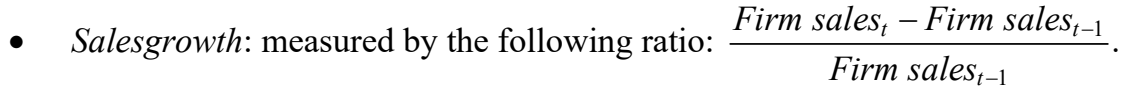

- Tangible: measuring the proportion of tangible assets relative to total assets: $\frac{\text { Tangible assets }}{\text { Total assets }}$.

\section{Descriptive statistics and univariate analysis}

\subsection{Descriptive statistics}

Table 2 panel A reports summary statistics for our variables of risk-taking, family ownership and control variables. In this table, we use the entire sample including family and non-family firms. The variables Risk1 and Risk2 have an average of 0.042. The median value of the variable Risk1 is 0.027 and that of Risk 2 is 0.029 . These values are comparable to those found by similar studies in other contexts such as John et al. (2008) and Boubakri et al. (2013). The mean (median) of the equity stake belonging to families is $40.1 \%(44.5 \%)$. This finding shows the importance of family ownership. It is not surprising since the majority of our sample firms are family owned and families are dominant owners in Tunisia.

Table 2 panel A shows also that firms of our sample are large, have existed for a long period (the mean of their age is 26 years) and appear to be profitable (the mean value of the variable profitability is $11.6 \%$ ). In contrast, they are highly leveraged and grow slowly (the mean value of sales growth is 0.097 ). Moreover, tangible assets of these firms represent on average one third of total assets.

Table 2 panel B presents correlation coefficients between these variables. Family ownership seems to be negatively correlated to variables of risk-taking but this correlation is not significant. Furthermore, risk-taking is negatively related to firm size and positively associated to firm leverage, profitability and tangible assets. This means that firms undertaking more risky projects are smaller, more leveraged, more profitable and investing more in tangible assets. 
Table 2 Descriptive statistics (total sample)

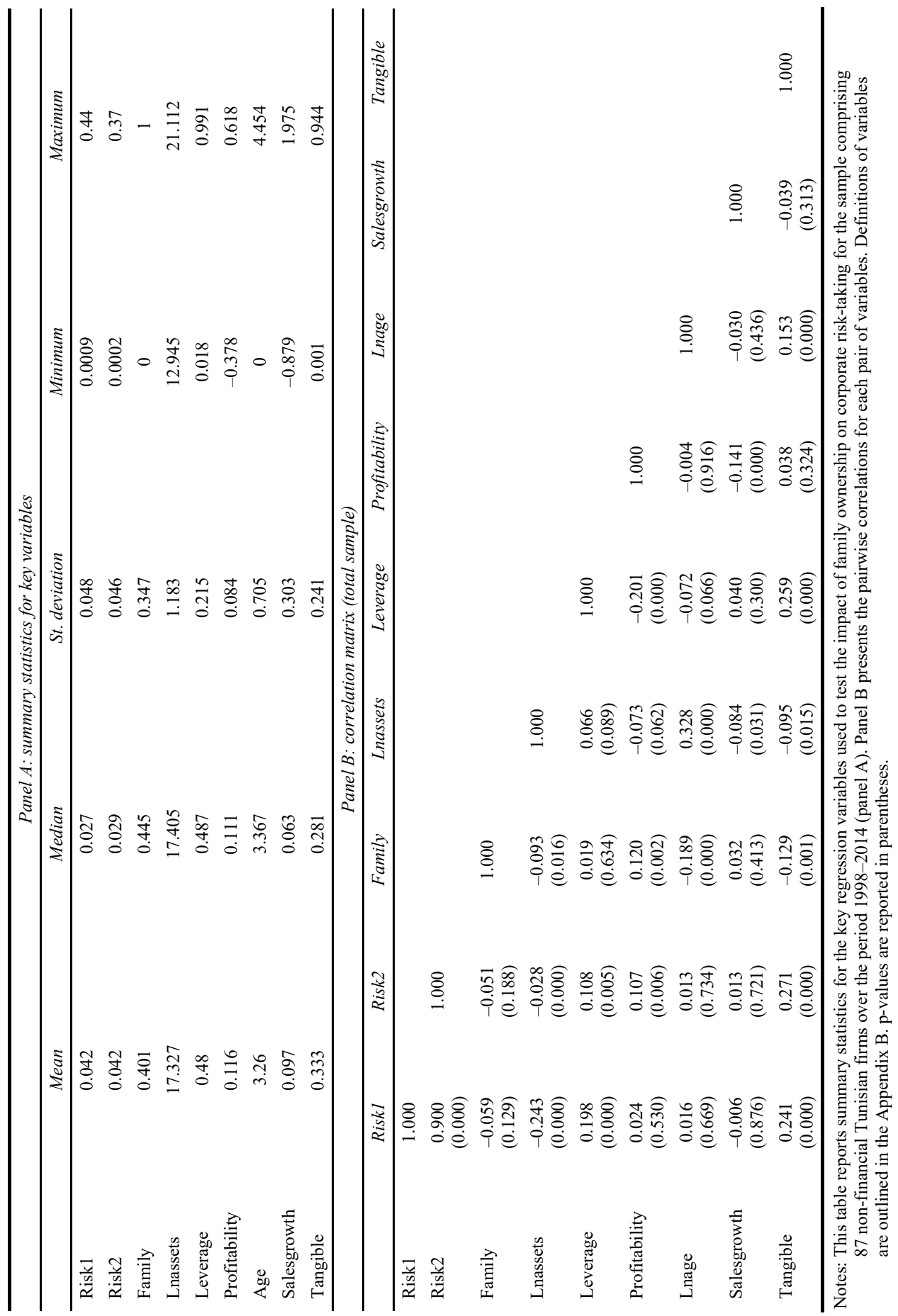




\subsection{Univariate analysis}

In Table 3, using the sample of only family firms, we operate univariate tests on risk-taking. In each panel of this table, we carry-out group mean comparison tests after splitting the sample of family firms into two subsamples (groups). In panel A, we compare the means of risk-taking proxies (Risk1 and Risk2) for sub-samples of high and low family ownership. To distinguish the two groups, we use an indicator variable that equals one if the variable family is higher than the median value and zero otherwise. We find that Risk1 and Risk2 are higher for the sub-sample of firms with higher family ownership but the difference is not significant.

Table 3 Group-mean comparison tests of risk-taking (sample of family firms)

\begin{tabular}{|c|c|c|c|c|}
\hline \multicolumn{5}{|c|}{ Panel $A$} \\
\hline & High family ownership & Low family ownership & Difference & $p$-value \\
\hline Risk 1 & 0.0392 & 0.0374 & 0.0018 & 0.5976 \\
\hline Risk 2 & 0.0393 & 0.0391 & 0.0005 & 0.8883 \\
\hline \multicolumn{5}{|c|}{ Panel B } \\
\hline & Group affiliation & No group affiliation & Difference & $p$-value \\
\hline Risk 1 & 0.0352 & 0.0472 & $-0.012 * * *$ & 0.002 \\
\hline Risk 2 & 0.0363 & 0.0482 & $-0.0119 * * *$ & 0.0044 \\
\hline \multicolumn{5}{|c|}{ Panel C } \\
\hline & Family management & No family management & Difference & $p$-value \\
\hline Risk 1 & 0.0372 & 0.0399 & -0.0027 & 0.4424 \\
\hline Risk 2 & 0.038 & 0.0414 & -0.0034 & 0.3728 \\
\hline \multicolumn{5}{|c|}{ Panel D } \\
\hline & Founder management & No founder management & Difference & $p$-value \\
\hline Risk 1 & 0.0427 & 0.0351 & $0.0075^{* *}$ & 0.0287 \\
\hline Risk 2 & 0.0442 & 0.0358 & $0.0083 * *$ & 0.0248 \\
\hline \multicolumn{5}{|c|}{ Panel E } \\
\hline & Succession & No succession & Difference & $p$-value \\
\hline Risk 1 & 0.0309 & 0.0394 & $-0.0084^{*}$ & 0.0962 \\
\hline Risk 2 & 0.0295 & 0.0408 & $-0.0112^{* *}$ & 0.0394 \\
\hline
\end{tabular}

Notes: This table presents univariate tests on risk-taking for the sample of 69 Tunisian family firms. In each panel of this table, we carry out group mean comparison tests after splitting the sample of family firms into two subsamples. The asterisks $*, * *$ and $* * *$ denote statistical significance at $10 \%, 5 \%$ and $1 \%$ levels respectively. Definitions of variables are outlined in the Appendix B.

Panel B of Table 3 reports group mean comparison tests between subsamples of firms affiliated to a group and those non-affiliated. Risk1 and Risk2 are significantly lower for group affiliated firms. This finding contradicts our Hypothesis 2 predicting that firms affiliated to a group take more risky projects due to their diversification and their ability to enhance innovation. 
In panel $\mathrm{C}$, we compare the means of risk-taking between firms managed by a member of the family and those where the manager does not belong to the family. We find that the differences between the group means are not significant either for Risk1 or Risk2.

Panel D compares risk-taking between the subsample of firms managed by the founder and that of firms not managed by the founder. The result shows that if the founder is the executive officer, the firm undertakes significantly more risky projects.

Finally, in panel E of Table 3, we compare firms for which descendants of the founder are the main owners and those where the founder is still the main shareholder. We observe that firms undertake significantly less risk when there is a succession of the ownership to the next generation.

Overall, these univariate tests support our Hypotheses 4 and 5 denoting that family firms undertake more risky projects when the founder is still active (either as manager or main shareholder) but do not confirm our Hypothesis 2. It must be noted that these tests provide only binary relations and do not take into account the impact of other potential explanatory variables. A multivariate analysis (which is the subject of the following sections) would be more appropriate.

\section{Multivariate analysis}

In this section, we report our regression results on the impact of family ownership, group affiliation and firm governance characteristics on risk-taking using our panel data of family and non-family Tunisian firms. To deal, at the same time, with issues of heterogeneity, simultaneity and dynamic endogeneity, we estimate all our models using the dynamic GMM estimator of Blundell and Bond (1998).

\subsection{The impact of family ownership on risk-taking}

We first estimate the following equation using the entire sample including family and non-family firms from 1998 to $2011:^{5}$

$$
\text { Risk }_{i t}=\propto+\beta \text { Risk }_{i t-1}+\text { SFamily Ownership }_{i t-1}+\mu \text { Controls }_{i t-1}+\varepsilon_{i t}
$$

where Risk refers to earnings volatility over four-year overlapping periods. The impact of family ownership is analysed using the variables family (the percentage of ownership stakes belonging to the family) and D-family (a dummy variable that equals one if the ownership stake belonging to family members exceeds $5 \%$ and zero otherwise). Controls denote the set of control variables (lnassets, leverage, profitability, age, salesgrowth, and tangible) and $\varepsilon_{i t}$ is an error term.

Note that all the independent variables enter the regression with their lagged values in order to reduce reverse causality.

As we can see from Table 4, there is a positive impact of family ownership on firm risk-taking. The variable family is significant only for the model explaining Risk2. In contrast, the variable D-family is significant at the $1 \%$ level for the model of Risk1 and at the 5\% level for the model of Risk2. This finding provides support for our Hypothesis 1 , indicating that Tunisian family firms are risk willing in order to preserve the family's 
socio-emotional wealth and to realise better performance as argued by the behavioural theory (Gómez-Mejía et al., 2007).

Table 4 The impact of family ownership on risk-taking

\begin{tabular}{|c|c|c|c|c|}
\hline \multirow{2}{*}{ Variable } & \multicolumn{2}{|c|}{ Model 1} & \multicolumn{2}{|c|}{ Model 2} \\
\hline & Risk1 & Risk2 & Risk1 & Risk2 \\
\hline Constant & $\begin{array}{l}0.080^{* *} \\
(0.041)\end{array}$ & $\begin{array}{c}0.341 \\
(0.309)\end{array}$ & $\begin{array}{c}0.072 * * * \\
(0.009)\end{array}$ & $\begin{array}{c}0.029 \\
(0.337)\end{array}$ \\
\hline Risk1 (t-1) & $\begin{array}{c}0.629 * * * \\
(0.000)\end{array}$ & & $\begin{array}{c}0.690 * * * \\
(0.000)\end{array}$ & \\
\hline Risk2 (t-1) & & $\begin{array}{c}0.757 * * * \\
(0.000)\end{array}$ & & $\begin{array}{c}0.777 * * * \\
(0.000)\end{array}$ \\
\hline Family & $\begin{array}{c}0.015 \\
(0.255)\end{array}$ & $\begin{array}{l}0.021 * \\
(0.053)\end{array}$ & & \\
\hline D-family & & & $\begin{array}{c}0.012 * * * \\
(0.001)\end{array}$ & $\begin{array}{c}0.013 * * \\
(0.039)\end{array}$ \\
\hline Lnassets & $\begin{array}{c}-0.005^{* *} \\
(0.013)\end{array}$ & $\begin{array}{l}-0.002 \\
(0.205)\end{array}$ & $\begin{array}{c}-0.047 * * * \\
(0.004)\end{array}$ & $\begin{array}{l}-0.002 \\
(0.248)\end{array}$ \\
\hline Leverage & $\begin{array}{l}-0.002 \\
(0.388)\end{array}$ & $\begin{array}{l}-0.002 \\
(0.415)\end{array}$ & $\begin{array}{c}-0.002 \\
(0.288)\end{array}$ & $\begin{array}{l}-0.005 \\
(0.789)\end{array}$ \\
\hline Profitability & $\begin{array}{c}-0.046^{* * *} \\
(0.000)\end{array}$ & $\begin{array}{c}-0.028^{*} \\
(0.09)\end{array}$ & $\begin{array}{c}-0.065^{* * *} \\
(0.000)\end{array}$ & $\begin{array}{c}-0.025^{* *} \\
(0.020)\end{array}$ \\
\hline Age & $\begin{array}{c}0.007 * * * \\
(0.003)\end{array}$ & $\begin{array}{c}0.030 \\
(0.102)\end{array}$ & $\begin{array}{c}0.006 * * * \\
(0.001)\end{array}$ & $\begin{array}{c}0.002 \\
(0.305)\end{array}$ \\
\hline Salesgrowth & $\begin{array}{c}0.001 \\
(0.358)\end{array}$ & $\begin{array}{l}0.003 * \\
(0.073)\end{array}$ & $\begin{array}{c}0.027 * * * \\
(0.007)\end{array}$ & $\begin{array}{l}0.003 * * \\
(0.018)\end{array}$ \\
\hline Tangible & $\begin{array}{c}0.007 * * * \\
(0.000)\end{array}$ & $\begin{array}{c}0.006^{* * * *} \\
(0.000)\end{array}$ & $\begin{array}{c}0.007 * * * \\
(0.000)\end{array}$ & $\begin{array}{l}0.006 * * * \\
(0.000)\end{array}$ \\
\hline Wald $\chi^{2}$ & $913.11 * * *$ & $1,829.84 * * *$ & $1,558.72 * * *$ & $2,928.62 * * *$ \\
\hline Prob $>\chi^{2}$ & $(0.000)$ & $(0.000)$ & $(0.000)$ & $(0.000)$ \\
\hline Observations & 568 & 568 & 568 & 568 \\
\hline $\mathrm{AR}(1)$ test & $\mathrm{p}=0.056$ & $\mathrm{p}=0.016$ & $\mathrm{p}=0.057$ & $\mathrm{p}=0.016$ \\
\hline $\mathrm{AR}(2)$ test & $\mathrm{p}=0.138$ & $p=0.634$ & $p=0.106$ & $\mathrm{p}=0.322$ \\
\hline $\begin{array}{l}\text { Hansen test of over- } \\
\text { identification }\end{array}$ & $\mathrm{p}=0.121$ & $\mathrm{p}=0.237$ & $p=0.243$ & $\mathrm{p}=0.468$ \\
\hline
\end{tabular}

Notes: This table presents regression results of the equation (1) testing the impact of family ownership on corporate risk-taking. The dependent variables Risk1 and Risk2 are measures of corporate risk-taking. Dynamic models are estimated using the system GMM of Blundell and Bond (1998). The GMM models include one lag of the dependent variable. Definitions of variables are outlined in the Appendix B. The sample includes 87 non-financial Tunisian firms over the period 1998-2014. p-values are reported in parentheses with $*, * *$ and $* * *$ denoting statistical significance at $10 \%, 5 \%$ and $1 \%$ level respectively. AR(1) and $A R(2)$ are tests for first-order and second-order serial correlation in the first-differenced residuals, under the null of no serial correlation. The Hansen test of over-identification is under the null that all instruments are valid. 
Also, our result can be explained referring to the agency theory predicting that the alignment of interests between managers and shareholders ensures effective decision making perpetuating the continuity of the firm (Berle and Means, 1932; Jensen and Meckling, 1976). According to the supporters of this theory, family owners undertake more efficient investments with an eye on the long term. They are expected to invest in risky projects in order to support radical innovations that enhance organisational growth (Zahra, 2005; Nguyen, 2011; Schmid et al., 2014).

Furthermore, strategic management researchers link the higher risk of family firms to their greater competitive advantages, which explains their higher profitability and growth rates (Nguyen, 2011).

Turning to the control variables, we find that firm size (lnassets) is negatively related to Risk1 and Risk2 and is statistically significant for models explaining Risk1. This result suggests that larger firms are more able to manage risks than smaller ones due to their greater ability to diversify risk across product lines (Nguyen, 2011). Leverage is insignificantly associated to firm risk, consistent with Cheng (2008) who finds no effect of the leverage ratio on the return volatility of US firms. In addition, profitability is negatively related to risk-taking which is in line with the presumption that lower profitability could be associated to more risk-taking (Boubakri et al., 2013). Firm age also appears to produce an increase in risk-taking. We also find that salesgrowth loads positively and is statically significant. Then, firms with more growth opportunities present a higher risk profile, consistent with the large uncertainty surrounding their future cash-flows. Finally, the ratio of fixed to total assets (tangible) is positively related to firm risk. This result is surprising since it is not consistent with the predictions suggesting that more risk-taking should be associated with more intangible and R\&D investments.

\subsection{Group affiliation and risk-taking in family firms}

In this section, we examine whether the affiliation of family firms to groups affect their risk-taking behaviour. Therefore, we exclude non-family firms from the entire sample to test the impact of group affiliation and diversification inside the group on risk-taking of family firms. Our sample is then limited to 69 firms and 358 observations. The following equation is considered:

$$
\text { Risk }_{i t}=\propto+\beta \text { Risk }_{i t-1}+\delta \text { Group affiliation }_{i t-1}+\mu \text { Controls }_{i t-1}+\varepsilon_{i t}
$$

We estimate three models. In the first one (model 3), we use the variable group which is a dummy variable that equals one if the firm is a member of a business group and zero otherwise. In models 4 and 5, we test the impact of diversification on risk-taking by including $\mathrm{Nb}-\mathrm{FG}$ and $\mathrm{Nb}-\mathrm{IG}$ as independent variables. In fact, diversification is measured either by the number of firms or the number of industries inside each group. Results are reported in Table 5 .

The coefficient on group variable is negative and insignificant. The results show that group affiliation do not affect risk-taking. Hypothesis 2 is then rejected.

In contrast, the coefficients on $\mathrm{Nb}-\mathrm{FG}$ and $\mathrm{Nb}-\mathrm{IG}$ are positive and statically significant indicating that well-diversified group affiliated family firms undertake riskier investments than non-diversified ones confirming Hypothesis 3. Then, although the literature predicts that group affiliation provides stability, reduces financial constraints and enhances innovation, our results show that for our sample of Tunisian firms, it is beneficial only if the degree of diversification is greater than a certain threshold (Faccio et al., 2011). 
Table 5 Group affiliation, diversification and risk-taking in family firms

\begin{tabular}{|c|c|c|c|c|c|c|}
\hline \multirow[b]{2}{*}{ Variable } & \multicolumn{2}{|c|}{ Model 3} & \multicolumn{2}{|c|}{ Model 4} & \multicolumn{2}{|c|}{ Model 5} \\
\hline & Risk1 & Risk2 & Risk1 & Risk2 & Risk1 & Risk2 \\
\hline Constant & $\begin{array}{c}0.055^{* *} \\
(0.016)\end{array}$ & $\begin{array}{c}0.009 \\
(0.505)\end{array}$ & $\begin{array}{c}0.027 \\
(0.266)\end{array}$ & $\begin{array}{c}0.059 * * * \\
(0.005)\end{array}$ & $\begin{array}{c}0.062 * * * \\
(0.004)\end{array}$ & $\begin{array}{c}0.164 * * * \\
(0.000)\end{array}$ \\
\hline Risk1 (t-1) & $\begin{array}{c}0.777 * * * \\
(0.000)\end{array}$ & & $\begin{array}{c}0.646^{* * * *} \\
(0.000)\end{array}$ & & $\begin{array}{c}0.665^{* * *} * \\
(0.000)\end{array}$ & \\
\hline Risk2 (t-1) & & $\begin{array}{c}0.743 * * * \\
(0.000)\end{array}$ & & $\begin{array}{c}0.777 * * * \\
(0.000)\end{array}$ & & $\begin{array}{c}0.770 * * * \\
(0.000)\end{array}$ \\
\hline Group & $\begin{array}{l}-0.004 \\
(0.420)\end{array}$ & $\begin{array}{l}-0.007 \\
(0.168)\end{array}$ & & & & \\
\hline $\mathrm{Nb}-\mathrm{FG}$ & & & $\begin{array}{c}-0.0004 \\
(0.786)\end{array}$ & $\begin{array}{c}0.011 * * * \\
(0.000)\end{array}$ & & \\
\hline $\mathrm{Nb}-\mathrm{IG}$ & & & & & $\begin{array}{c}0.008 * * * \\
(0.000)\end{array}$ & $\begin{array}{c}0.025 * * * \\
(0.000)\end{array}$ \\
\hline Lnassets & $\begin{array}{l}-0.002 \\
(0.115)\end{array}$ & $\begin{array}{l}0.0005 \\
(0.647)\end{array}$ & $\begin{array}{c}-0.0001 \\
(0.930)\end{array}$ & $\begin{array}{c}-0.004 * * * \\
(0.002)\end{array}$ & $\begin{array}{c}-0.003 * * \\
(0.015)\end{array}$ & $\begin{array}{c}-0.010 * * * \\
(0.000)\end{array}$ \\
\hline Leverage & $\begin{array}{l}-0.003 \\
(0.298)\end{array}$ & $\begin{array}{l}-0.002 \\
(0.192)\end{array}$ & $\begin{array}{c}-0.008^{* * *} \\
(0.001)\end{array}$ & $\begin{array}{l}-0.004 \\
(0.116)\end{array}$ & $\begin{array}{c}-0.005^{* *} \\
(0.042)\end{array}$ & $\begin{array}{c}-0.006^{* *} \\
(0.031)\end{array}$ \\
\hline Profitability & $\begin{array}{c}-0.038^{* * *} \\
(0.001)\end{array}$ & $\begin{array}{l}-0.004 \\
(0.677)\end{array}$ & $\begin{array}{c}-0.013 * * \\
(0.015)\end{array}$ & $\begin{array}{c}-0.024^{*} \\
(0.064)\end{array}$ & $\begin{array}{c}-0.016^{* *} \\
(0.032)\end{array}$ & $\begin{array}{c}-0.140 * * * \\
(0.000)\end{array}$ \\
\hline Age & $\begin{array}{l}-0.002 \\
(0.103)\end{array}$ & $\begin{array}{c}-0.0007 \\
(0.432)\end{array}$ & $\begin{array}{c}-0.0009 \\
(0.466)\end{array}$ & $\begin{array}{c}-0.0004 \\
(0.746)\end{array}$ & $\begin{array}{c}-0.0003 \\
(0.708)\end{array}$ & $\begin{array}{l}0.0009 \\
(0.684)\end{array}$ \\
\hline Salesgrowth & $\begin{array}{c}0.003 * * * \\
(0.000)\end{array}$ & $\begin{array}{c}0.004 * * * \\
(0.000)\end{array}$ & $\begin{array}{c}-0.003 * * * \\
(0.005)\end{array}$ & $\begin{array}{c}-0.005 * * * \\
(0.000)\end{array}$ & $\begin{array}{c}-0.003^{* * *} \\
(0.000)\end{array}$ & $\begin{array}{c}-0.005^{* * *} \\
(0.000)\end{array}$ \\
\hline Tangible & $\begin{array}{c}-0.0009 \\
(0.965)\end{array}$ & $\begin{array}{l}0.0004 \\
(0.812)\end{array}$ & $\begin{array}{c}-0.006^{* *} \\
(0.033)\end{array}$ & $\begin{array}{c}-0.006^{* * *} \\
(0.014)\end{array}$ & $\begin{array}{c}-0.011 * * * \\
(0.000)\end{array}$ & $\begin{array}{c}-0.011^{* * *} \\
(0.001)\end{array}$ \\
\hline Wald $\chi^{2}$ & $2,044 * * *$ & $2,141 * * *$ & $46,682 * * *$ & $159,925 * * *$ & $38,255 * * *$ & $672,358 * * *$ \\
\hline Prob $>\chi^{2}$ & $(0.000)$ & $(0.000)$ & $(0.000)$ & $(0.000)$ & $(0.000)$ & $(0.000)$ \\
\hline Observations & 358 & 358 & 259 & 259 & 259 & 259 \\
\hline $\mathrm{AR}(1)$ test & $\mathrm{p}=0.002$ & $\mathrm{p}=0.011$ & $\mathrm{p}=0.035$ & $\mathrm{p}=0.020$ & $\mathrm{p}=0.029$ & $\mathrm{p}=0.024$ \\
\hline $\mathrm{AR}(2)$ test & $p=0.465$ & $\mathrm{p}=0.149$ & $\mathrm{p}=0.433$ & $\mathrm{p}=0.501$ & $\mathrm{p}=0.447$ & $\mathrm{p}=0.391$ \\
\hline $\begin{array}{l}\text { Hansen test } \\
\text { of over- } \\
\text { identification }\end{array}$ & $\mathrm{p}=0.391$ & $\mathrm{p}=0.535$ & $\mathrm{p}=0.340$ & $p=0.734$ & $\mathrm{p}=0.395$ & $p=0.615$ \\
\hline
\end{tabular}

Notes: This table presents regression results of the equation (2) testing the impact of group affiliation and diversification inside groups on corporate risk-taking of Tunisian family firms. The dependent variables Risk1 and Risk $\mathbf{2}$ are measures of corporate risk-taking. Dynamic models are estimated using the system GMM of Blundell and Bond (1998). The GMM models include one lag of the dependent variable. Definitions of variables are outlined in the Appendix B. The sample includes 69 non-financial Tunisian family firms over the period 1998-2014. p-values are reported in parentheses with $*, * *$ and $* * *$ denoting statistical significance at $10 \%, 5 \%$ and $1 \%$ level respectively. AR(1) and AR(2) are tests for first-order and second-order serial correlation in the first-differenced residuals, under the null of no serial correlation. The Hansen test of over-identification is under the null that all instruments are valid. 
Table 6 Governance characteristics and risk-taking in family firms

\begin{tabular}{|c|c|c|c|c|c|c|}
\hline Variable & Model 6 & Model 7 & Model 8 & Model 9 & Model 10 & Model 11 \\
\hline Constant & $\begin{array}{c}0.001 \\
(0.942)\end{array}$ & $\begin{array}{l}-0.017 \\
(0.146)\end{array}$ & $\begin{array}{c}0.012 \\
(0.410)\end{array}$ & $\begin{array}{c}-0.0007 \\
(0.950)\end{array}$ & $\begin{array}{c}0.043 * * * \\
(0.004)\end{array}$ & $\begin{array}{c}0.029 * * * \\
(0.000)\end{array}$ \\
\hline Risk1 $(\mathrm{t}-1)$ & $\begin{array}{c}0.768 * * * \\
(0.000)\end{array}$ & $\begin{array}{c}0.771 * * * \\
(0.000)\end{array}$ & $\begin{array}{c}0.729 * * * \\
(0.000)\end{array}$ & $\begin{array}{c}0.762 * * * \\
(0.000)\end{array}$ & $\begin{array}{c}0.817 * * * \\
(0.000)\end{array}$ & $\begin{array}{c}0.780 * * * \\
(0.000)\end{array}$ \\
\hline Family & $\begin{array}{c}0.054 * * * \\
(0.000)\end{array}$ & $\begin{array}{c}0.054 * * * \\
(0.000)\end{array}$ & $\begin{array}{c}0.042 * * * \\
(0.000)\end{array}$ & $\begin{array}{c}0.047 * * * \\
(0.000)\end{array}$ & $\begin{array}{c}0.004 \\
(0.158)\end{array}$ & $\begin{array}{c}0.029 * * * \\
(0.000)\end{array}$ \\
\hline Fam.manag & $\begin{array}{c}0.004 * * * \\
(0.001)\end{array}$ & & & & & \\
\hline Found.manag & & $\begin{array}{c}0.013 * * * \\
(0.000)\end{array}$ & & & & \\
\hline Latergen.manag & & & $\begin{array}{c}-0.027 * * * \\
(0.000)\end{array}$ & & & \\
\hline Found.sup & & & & $\begin{array}{c}0.005 * * * \\
(0.003)\end{array}$ & & \\
\hline Latergen.sup & & & & & $\begin{array}{c}-0.004 * * * \\
(0.007)\end{array}$ & \\
\hline Succession & & & & & & $\begin{array}{c}0.002 \\
(0.103)\end{array}$ \\
\hline Lnassets & $\begin{array}{c}-0.001 * * \\
(0.049)\end{array}$ & $\begin{array}{l}-0.009 \\
(0.234)\end{array}$ & $\begin{array}{l}-0.002 * \\
(0.052)\end{array}$ & $\begin{array}{l}-0.001 \\
(0.109)\end{array}$ & $\begin{array}{c}-0.002 * * \\
(0.046)\end{array}$ & $\begin{array}{c}-0.002 * * * \\
(0.000)\end{array}$ \\
\hline Leverage & $\begin{array}{c}-0.013^{* * *} \\
(0.000)\end{array}$ & $\begin{array}{c}-0.006^{* *} \\
(0.034)\end{array}$ & $\begin{array}{c}-0.005^{* *} \\
(0.036)\end{array}$ & $\begin{array}{c}-0.007 * * * \\
(0.008)\end{array}$ & $\begin{array}{l}-0.001 \\
(0.643)\end{array}$ & $\begin{array}{l}-0.005 \\
(0.117)\end{array}$ \\
\hline Profitability & $\begin{array}{c}-0.057 * * * \\
(0.000)\end{array}$ & $\begin{array}{c}-0.042 * * * \\
(0.000)\end{array}$ & $\begin{array}{c}-0.051 * * * \\
(0.000)\end{array}$ & $\begin{array}{c}-0.049 * * * \\
(0.000)\end{array}$ & $\begin{array}{c}-0.040 * * * \\
(0.000)\end{array}$ & $\begin{array}{c}-0.042 * * * \\
(0.000)\end{array}$ \\
\hline Age & $\begin{array}{c}0.004 * * \\
(0.016)\end{array}$ & $\begin{array}{c}0.005 * * * \\
(0.000)\end{array}$ & $\begin{array}{c}0.004 * * * \\
(0.000)\end{array}$ & $\begin{array}{c}0.003 * * * \\
(0.002)\end{array}$ & $\begin{array}{l}-0.0007 \\
(0.552)\end{array}$ & $\begin{array}{c}0.001 \\
(0.229)\end{array}$ \\
\hline Salesgrowth & $\begin{array}{c}0.004 * * * \\
(0.000)\end{array}$ & $\begin{array}{c}0.004 * * * \\
(0.000)\end{array}$ & $\begin{array}{c}0.003 * * * \\
(0.000)\end{array}$ & $\begin{array}{c}0.004 * * * \\
(0.000)\end{array}$ & $\begin{array}{c}0.004 * * * \\
(0.000)\end{array}$ & $\begin{array}{c}0.005 * * * \\
(0.000)\end{array}$ \\
\hline Tangible & $\begin{array}{c}-0.01 * * * \\
(0.000)\end{array}$ & $\begin{array}{c}-0.009 * * * \\
(0.000)\end{array}$ & $\begin{array}{c}-0.003 * \\
(0.084)\end{array}$ & $\begin{array}{c}-0.01 * * * \\
(0.000)\end{array}$ & $\begin{array}{c}-0.0007 \\
(0.711)\end{array}$ & $\begin{array}{c}-0.008 * * * \\
(0.000)\end{array}$ \\
\hline Wald $\chi^{2}$ & $38,299 * * *$ & $\underset{7 * * *}{1.15 \mathrm{e}+}$ & $15,296 * * *$ & $467,465 * * *$ & $2,903 * * *$ & $195,193 * * *$ \\
\hline Prob $>\chi^{2}$ & $(0.000)$ & $(0.000)$ & $(0.000)$ & $(0.000)$ & $(0.000)$ & $(0.000)$ \\
\hline Observations & 358 & 358 & 358 & 358 & 358 & 358 \\
\hline $\mathrm{AR}(1)$ test & $\mathrm{p}=0.007$ & $\mathrm{p}=0.007$ & $\mathrm{p}=0.006$ & $\mathrm{p}=0.007$ & $\mathrm{p}=0.005$ & $\mathrm{p}=0.006$ \\
\hline $\mathrm{AR}(2)$ test & $\mathrm{p}=0.500$ & $\mathrm{p}=0.529$ & $\mathrm{p}=0.551$ & $\mathrm{p}=0.543$ & $\mathrm{p}=0.461$ & $\mathrm{p}=0.432$ \\
\hline $\begin{array}{l}\text { Hansen test of } \\
\text { over-identification }\end{array}$ & $\mathrm{p}=0.494$ & $\mathrm{p}=0.667$ & $\mathrm{p}=0.637$ & $\mathrm{p}=0.709$ & $\mathrm{p}=0.904$ & $\mathrm{p}=0.763$ \\
\hline
\end{tabular}

Notes: This table presents regression results of the equation (3) testing the impact of governance characteristics (family management, the active role of the founder and succession) on corporate risk-taking of Tunisian family firms. The dependent variables Risk1 and Risk2 are measures of corporate risk-taking. Dynamic models are estimated using the system GMM of Blundell and Bond (1998). The GMM models include one lag of the dependent variable. Definitions of variables are outlined in the Appendix B. The sample includes 69 non-financial Tunisian family firms over the period 1998-2014. p-values are reported in parentheses with $*, * *$ and $* * *$ denoting statistical significance at $10 \%, 5 \%$ and $1 \%$ level respectively. AR(1) and $\mathrm{AR}(2)$ are tests for first-order and second-order serial correlation in the first-differenced residuals, under the null of no serial correlation. The Hansen test of over-identification is under the null that all instruments are valid. 
Because diversified groups derive greater utility of risk-taking, they are expected to be more prone to taking projects with more volatile earnings. Our results are in line with Khanna and Palepu (2000b) arguing that the most diversified groups are best suited to fill institutional voids; they add value for their affiliates, so the degree of diversification provides a main source of group benefits.

Focusing on control variables, it should be noted that the coefficients of lnassets and profitability keep the same sign with approximately the same significance level but that of the variable age is not significant. The coefficient of the leverage variable becomes negative and statically significant for some models. Such outcome corroborates the finding of Schmid et al. (2013). However, for the sub-sample of family firms belonging to a group (models 4 and 5), the variables salesgrowth and tangible become negative and statistically significant. These results suggest that family firms affiliated to a group do not undertake risky projects in case of growth opportunities. Furthermore, firms with more tangible assets take less risk, which is in line with the results of Schmid et al. (2013).

\subsection{Firm governance characteristics and risk-taking in family firms}

As in the previous section, we restrict our sample to family firms (69 firms) to best understand the role of family-firm governance characteristics in risk-taking. The following equation is then estimated:

$$
\text { Risk }_{i t}=\propto+\beta \text { Risk }_{i t-1}+\delta \text { Firm }_{\text {characteristics }} \text { it }-1_{1}+\mu \text { Controls }_{i t-1}+\varepsilon_{i t}
$$

Regression results are reported in Table 6.

As Table 6 indicates, in all the columns, the family ownership variable has the predicted sign and shows that family owned firms take higher risk.

The coefficient on family management variable is positive and statically significant at the $1 \%$ level. This result provides support for hypothesis H4, in line with agency and stewardship theories.

On the one hand, agency theorists content that owners-managers have the formal and informal powers that allow them to devote necessary resources to explore promising ideas and implement them in a timely fashion. Consequently, they take calculated risks worthwhile which leads to maximising their families' wealth (Zahra, 2005).

On the other hand, the stewardship theory posits that owners-managers of family firms often use their firms as vehicles for sustaining the family's trans-generational economic and socio-emotional needs (Cabrera-Suárez and Santana-Martín, 2015). These elements associated to stewardship attitudes can be also linked to the concept of altruism encouraging feelings of trust, facilitating communication between family members and resulting in reduced agency costs (Lubatkin et al., 2005; Gordini, 2016).

Furthermore, results show positive and significant relations between founder management, founder supervision and risk variables suggesting that the duality of being a founder and CEO or a founder and a chairman appears to have an important positive impact on Tunisian family firms' risk-taking. Results confirm the Hypothesis 5: the active role of founders as CEO and as supervisor of the firm. Firms that are managed by the founding family seem to have a longer investment horizon, leading to more risky projects. Indeed, the performance of family businesses is only better when the founder is still active in the firm, either as a CEO or a Chairman with a hired CEO (Villalonga and 
Amit, 2006; Andres, 2008; Muttakin et al., 2014). Then, firms controlled by their founders are more profitable and grow more rapidly than the other firms.

Moreover, the coefficients on later generation management and later generation supervision are negative and statically significant suggesting that family members of the second and later generations are less concerned about the continuity and the survival of their firms. Also, they may lack experience and competence to adequately manage the firm. Moreover, it has been argued that conflicts of interests are often higher when there is more than one generation (Villalonga and Amit, 2006; González-Cruz and Cruz-Ros, 2016).

Thus, our results show that founders play an active role and are even more risk takers than the next generations because they are more involved in the firm, more visionary and experienced and seek to perpetuate their family dynasty.

Note that these founders cannot be eternal and their firms will be transmitted to subsequent generations who are often more risk averse and have to manage potential conflicts of interest between shareholders. Therefore, founders must necessarily prepare their succession to later generations, especially when they control a group of companies with a complicated ownership structure. Thus, they must plan the involvement of each descendant in the management of their firms. For example, the creation of holdings is likely to ensure more efficient management and a better justice between the descendants.

As for the effect of ownership succession to the next generation on risk-taking, results show no significant impact. Thus, Hypothesis 6 has to be rejected. In Tunisia, there are few cases of family succession (it is only the case of the death of the founder or when the latter waives all his wealth to his descendants), that is why control right in hands of later generations cannot be an important issue that may affect firm value, risk and investment choices.

Finally, one can observe that estimations yield very similar results for the control variables to those presented in Tables 4 and 5. Compared to the results of Table 5, the variable salesgrowth becomes positive and strongly significant, which is more in line with the expectations.

\section{Further analysis: the interaction between family ownership and firm characteristics}

We extend our analysis to study the impact of family ownership when the firm is managed or supervised by a non-member of the family or a family member of a later generation.

For this purpose, we re-estimate our first equation by including additional independent variables. We consider three interactive variables by multiplying the variable family (proportion of family ownership) by each of the following dummy variables:

- Latergen.manag: equals one if a descendant of the founder is the CEO or the executive officer and zero otherwise.

- Latergen.sup: equals one if the chairman of the board of directors is one of the descendants of the founder and zero otherwise.

- No.Fam.Manag: equals one if the firm is managed by a non-member of the family and zero otherwise. 
Table 7 The interaction between family ownership and firm characteristics

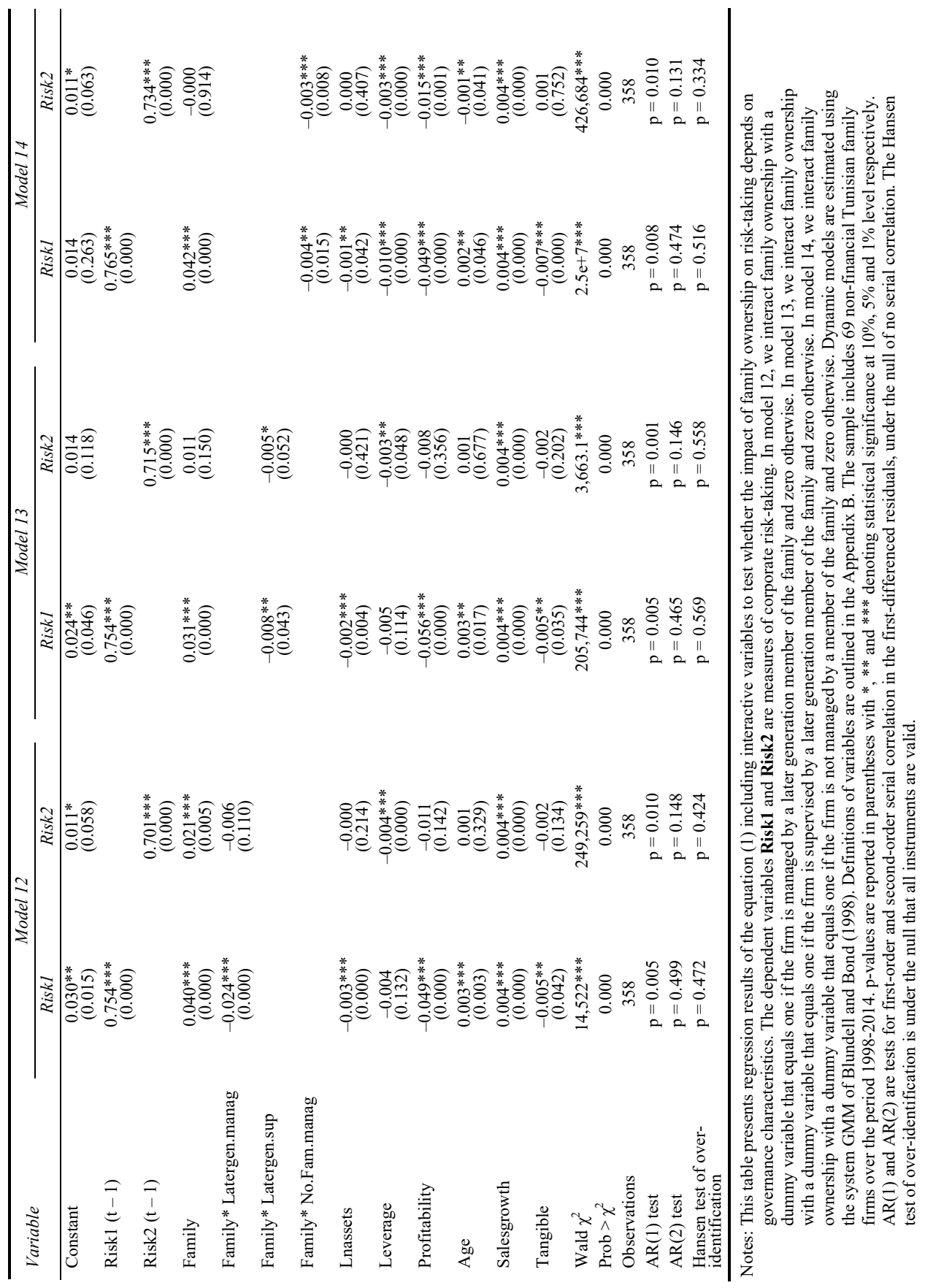


Our results are presented in Table 7 where we consider three models (in each model, we include an interactive variable).

In models 12, 13 and 14 of Table 7, we find that the interaction terms load negatively and statistically significant, suggesting that the impact of family ownership on risk-taking is rather negative when the manager is not a member of the family or when the CEO or the chairman is not the founder but one of his descendants.

Hence, for high levels of family ownership, a manager not belonging to the family avoids risk-taking in his investment choices. Also, in case of the management or the supervision of the firm by a member of the family other than the founder, the higher the proportion of family ownership, the lower the risk undertaken by family firms. Thus, arguments of the agency and behavioural theories no longer hold in these cases: family firms adopt rather a conservative orientation when the founder is not active or when the manager is not a member of the family.

\section{Robustness checks}

We conduct a set of robustness tests considering alternative sample selection criteria and specifications. These tests are not reported here for brevity.

\subsection{Alternative measures of corporate risk-taking}

To mitigate concerns that our results are driven by the proxy for risk-taking, we use alternative measures of corporate risk-taking Risk3 and Risk4. Risk3 is the volatility of EBITDA on sales and Risk4 is the volatility of EBIT on sales over four overlapping years (see Appendix B for more detailed definitions).

When considering Risk3 and Risk4 as dependent variables, our initial results remain unchanged. Family ownership still impacts positively risk-taking and diversification inside the group is positively related to risk-taking of firms. Moreover, firms are more likely to undertake value-enhancing risky projects when founders are still active and when the manager is a member of the family.

\subsection{Alternative measures of profitability and firm size}

Our second robustness check concerns alternative definitions of profitability and firm size. We re-estimate all our models using EBITDA/sales instead of EBITDA/assets as a proxy of profitability.

Similarly, all the models are re-estimated using the natural logarithm of total sales instead of total assets as a proxy of firm size. Regression results are qualitatively the same as those presented in Tables 4, 5, 6 and 7.

\subsection{Alternative sample excluding the after-revolution period}

Our sample includes all firms making public offerings for which data is available from 1998 to 2014 and we calculate variables of risk-taking over four overlapping years. Variables of risk-taking calculated using data from 2011 to 2014 may be influenced by the crisis involved in Tunisia after the revolution of January 2011. To mitigate concerns that our results are driven by these observations, we rerun our analyses using only 
observations of the period ' 1998 to 2010 ' for the determination of risk-taking variables. The results show that our main evidence is not affected except for some models where the coefficients are less significant. These findings could be explained by the decreasing number of observations.

\subsection{Alternative sample excluding commercial companies}

Since commercial companies do not undertake many risky projects like firms operating in other industries, we re-estimate all our models basing on a sample excluding commercial firms. The results continue to support our evidence.

\subsection{Additional control variables}

As a last robustness test, we include in our baseline regression two control variables: the ownership proportion of financial institutions and that of foreigners. The results show that financial institutions' ownership is negatively and significantly associated to risk-taking of firms which means that financial institutions in Tunisia, even as shareholders, seek to minimise the risk-taking. In contrast, the coefficient associated to foreigners' ownership is positive and significant meaning that this type of shareholders is more likely to adopt innovation investment projects which increases firms' earnings volatility.

Even after including these two variables, results of the other variables are qualitatively the same.

\section{Conclusions}

This paper investigates the impact of family ownership, business group affiliation and firm governance characteristics on corporate risk-taking behaviour on a dataset of 87 Tunisian non-financial firms from 1998 to 2014. We use the GMM technique of Blundell and Bond (1998) taking into account heterogeneity, simultaneity and endogeneity sources.

Our main findings indicate that Tunisian family firms take more risk than non-family ones. This effect is mainly driven by the desire of family owners to avoid losing their socio-emotional wealth and to make survival strategies ensuring better performance. Also, well-diversified group affiliated family firms undertake riskier investments than non-diversified ones. Hence, long-term position seems to overweight risk aversion in firms that are actively governed by families, especially those belonging to diversified groups. Furthermore, family firms undertake value-enhancing risky projects when the manager is a member of the family or when the founder is still active in the firm. Otherwise, family ownership becomes negatively associated to risk-taking. In fact, without the family involvement on the executive or the supervisory board, family firms seem to face agency-problems similar to those of non-family companies.

The findings contribute to a better understanding of family firms in general and their risk-taking behaviour in particular. They have some useful implications for investors and policy makers. Interestingly, the results underline the importance of family ownership for investment in more risky projects and innovative activities that enhance organisational 
growth within the economy. Also, our results reveal the importance to consider firms' governance characteristics, i.e., an active management role of the family or an active founder, as important determinants for family risk-taking behaviour. Furthermore, the high dependence between the affiliation of family firms to diversified groups operating in several industries and risk-taking behaviour would be an incentive for families to diversify their assets portfolio.

Since a significant increase in corporate risk-taking is an important driver of a country's economic growth and development, policy makers should encourage family firms, group diversification and focus on the investment horizons of decision makers to conduct innovative and productive projects. From this point of view, regulations and guiding principles for good corporate governance in Tunisia should be reviewed. Importantly, government should sustain family firms because they are the most efficient and profitable form of organisation. Also, it is worthwhile to make more attractive for founders to keep an active management role even after the firm's IPO. Furthermore, founders must plan and prepare their inheritance to later generations in order to motivate them to maintain their socio-emotional wealth and to be able to manage potential conflicts of interests. Consequently, they should define the role played by each descendant in the firm management. The holding creation may be a solution to achieve a better management and guarantee a better justice between the descendants.

\section{References}

Anderson, R.C. and Reeb, D.M. (2003) 'Founding-family ownership, corporate diversification and firm leverage', Journal of Law \& Economics, Vol. 46, No. 2, pp.653-680.

Anderson, R.C., Mansi, S.A. and Reeb, D.M. (2003) 'Founding family ownership and the agency cost of debt', Journal of Financial Economics, Vol. 68, No. 2, pp.263-285.

Andres, C. (2008) 'Large shareholders and firm performance - an empirical examination of founding-family ownership', Journal of Corporate Finance, Vol. 14, No. 4, pp.431-445.

Bamiatzi, V., Cavusgil, S.T., Jabbour, L. and Sinkovics, R.R. (2014) 'Does business group affiliation help firms achieve superior performance during industrial downturns? An empirical examination', International Business Review, Vol. 23, No. 1, pp.195-211.

Barontini, R. and Caprio, L. (2006) 'The effect of family control on firm value and performance: evidence from continental Europe', European Financial Management, Vol. 12, No. 5, pp.689-723.

Benmostefa, F. (2015) La Transmission des Entreprises Familiales en Tunisie, PhD thesis in Management, Bordeaux University.

Berle, A. and Means, G. (1932) The Modern Corporation and Private Property, Macmillan, New York.

Blundell, R. and Bond, S. (1998) 'Initial conditions and moment restrictions in dynamic panel data models', Journal of Econometrics, Vol. 87, No. 1, pp.115-143.

Boubakri, N., Cosset, J.C. and Saffar, W. (2013) 'The role of state and foreign owners in corporate risk-taking: evidence from privatization', Journal of Financial Economics, Vol. 108, No. 3, pp.641-658.

Byun, H.Y., Choi, S., Hwang, L.S. and Kim, R.G. (2013) 'Business group affiliation, ownership structure, and the cost of debt', Journal of Corporate Finance, Vol. 23, pp.311-331.

Cabrera-Suárez, K. and Santana-Martín, D.J. (2015) 'Board composition and performance in Spanish non-listed family firms: the influence of type of directors and CEO duality', Business Research Quarterly, Vol. 18, No. 4, pp.213-229. 
Chang, S.J. and Choi, U. (1988) 'Strategy, structure and performance of Korean business groups: a transactions cost approach', Journal of Industrial Economics, Vol. 37, No. 2, pp.141-158.

Cheng, S. (2008) 'Board size and the variability of corporate performance', Journal of Financial Economics, Vol. 87, No. 1, pp.157-176.

Choi, Y.R., Zahra, S.A., Yoshikawa, T. and Han, B.H. (2015) 'Family ownership and R\&D investment: the role of growth opportunities and business group membership', Journal of Business Research, Vol. 68, No. 5, pp.1053-1061.

Claessens, S., Djankov, S. and Lang, L.H.P. (2002) 'Disentangling the incentive and entrenchment effects of large shareholdings', Journal of Finance, Vol. 57, No. 6, pp.2741-2771.

Demsetz, H. (1983) 'The structure of ownership and the theory of the firm', Journal of Law and Economics, Vol. 26, No. 2, pp.375-390.

Demsetz, H. and Lehn, K. (1985) 'The structure of corporate ownership: causes and consequences', Journal of Political Economy, Vol. 93, No. 6, pp.1155-1177.

Erbetta, F., Menozzi, A., Corbetta, G. and Fraquelli, G. (2013) 'Assessing family firm performance using frontier analysis techniques: evidence from Italian manufacturing industries', Journal of Family Business Strategy, Vol. 4, No. 2, pp.106-117.

Faccio, M., Marchica, M. and Mura, R. (2011) 'Large shareholder diversification and corporate risk-taking', Review of Financial Studies, Vol. 24, No. 11, pp.3601-3641.

Gharbi, Y. and Ben Ouda, O. (2011) 'Ultimate ownership structure and stock liquidity: empirical evidence from Tunisia', Studies in Economics and Finance, Vol. 28, No. 4, pp.282-300.

Gherib, J. and Souissi, L. (2004) 'Processus de décision stratégique et performance de l'entreprise: cas des entreprises familiales tunisiennes de secteur des services', Conference act of the International Association of Strategic Management, Normandy, June.

Gómez-Mejía, L.R., Haynes, K.T., Núñez-Nickel, M., Jacobson, K.J.L. and Moyano-Fuentes, J. (2007) 'Socioemotional wealth and business risks in family-controlled firms: evidence from Spanish olive mills', Administrative Science Quarterly, Vol. 52, No. 1, pp.106-137.

González-Cruz, T.F. and Cruz-Ros, S. (2016) 'When does family involvement produce superior performance in SME family business?', Journal of Business Research, Vol. 69, No. 4, pp.1452-1457.

Gordini, N. (2016) 'Does the family status of the CFO matter to enhance family firm performance? Evidence from a sample of small and medium-sized Italian family firms', International Journal of Entrepreneurship and Small Business, Vol. 28, No. 1, pp.36-57.

Guillen, M.F. (2000) 'Business groups in emerging economies: a resource-based view', The Academy of Management Journal, Vol. 43, No. 3, pp.362-380.

Jensen, M.C. and Meckling, W.H. (1976) 'Theory of the firm: managerial behavior, agency costs and ownership structure', Journal of Financial Economics, Vol. 3, No. 4, pp.305-360.

John, K., Litov, L. and Yeung, B. (2008) 'Corporate governance and risk-taking', Journal of Finance, Vol. 63, No. 4, pp.1679-1728.

Khanchel, I. (2007) 'Empirical evidence on corporate governance and corporate performance in Tunisia', Corporate Governance: An International Review, Vol. 15, No. 6, pp.1429-1441.

Khanna, T. and Palepu, K. (2000a) 'The future of business groups in emerging markets: long-run evidence from Chile', The Academy of Management Journal, Vol. 43, No. 3, pp.268-285.

Khanna, T. and Palepu, K. (2000b) 'Is group affiliation profitable in emerging markets: an analysis of Indian diversified business groups', Journal of Finance, Vol. 55, No. 2, pp.867-891.

Kim, Y. and Lui, S.S. (2015) 'The impacts of external network and business group on innovation: do the types of innovation matter?', Journal of Business Research, Vol. 68, No. 9, pp.1964-1973.

La Porta, R., Lopez-de-Silanes, F. and Shleifer, A. (1999) 'Corporate ownership around the world', Journal of Finance, Vol. 54, No. 2, pp.471-517. 
Lensink, R. and Molen, R. (2010) 'Does group affiliation increase firm value for diversified groups? New evidence from Indian companies', Journal of Empirical Finance, Vol. 17, No. 3, pp.332-344.

Lubatkin, M.H., Schulze, W.S., Ling, Y. and Dino, R.N. (2005) 'The effects of parental altruism on the governance of family-managed firms', Journal of Organizational Behavior, Vol. 26, No. 3, pp.313-330.

Madani, W. (2010) L'efficacité du Conseil D'administration Dans les Entreprises Familiales: Etude de ses Déterminants Dans le Contexte Tunisien, $\mathrm{PhD}$ thesis in Accounting Sciences, Higher Institute of Accounting and Business Administration, Manouba University.

Masmoudi, A. and Gherib, J. (2004) 'Rapidité et performance: cas des entreprises industrielles familiales tunisiennes', Conference act of the International Association of Strategic Mnanagement, Normandy, June.

McConaughy, D.L., Matthews, C.H. and Fialko, A.S. (2001) 'Founding family controlled firms: performance, risk, and value', Journal of Small Business Management, Vol. 39, No. 1, pp.31-49.

Miller, D., Breton-Miller, I.L., Lester, R.H. and Cannella Jr., A.A. (2007) 'Are family firms really superior performers?', Journal of Corporate Finance, Vol. 13, No. 5, pp.829-858.

Mishra, C.S. and McConaughy, D.L. (1999) 'Founding family control and capital structure: the risk of loss of control and the aversion to debt', Entrepreneurship: Theory and Practice, Vol. 23, No. 4, pp.53-65.

Mnasri, K. and Ellouze, D. (2015) 'Ownership structure, product market competition and productivity: evidence from Tunisia', Management Decision, Vol. 53, No. 8, pp.1771-1805.

Morck, R. and Yeung, B. (2003) 'Agency problems in large family business groups', Entrepreneurship Theory and Practice, Vol. 27, No. 4, pp.367-382.

Morck, R., Strangeland, D.A. and Yeung, B. (2000) 'Inherited wealth, corporate control, and economic growth: the Canadian disease', in Morck, P. (Ed.): Concentrated Corporate Ownership, pp.319-369, University of Chicago Press, Chicago.

Muttakin, M.B., Khan, A. and Subramaniam, N. (2014) 'Family firms, family generation and performance: evidence from an emerging economy', Journal of Accounting in Emerging Economies, Vol. 4, No. 2, pp.197-219.

Nguyen, P. (2011) 'Corporate governance and risk-taking: evidence from Japanese firms', PacificBasin Finance Journal, Vol. 19, No. 3, pp.278-297.

Paligorova, T. (2010) Corporate Risk-Taking and Ownership Structure, Bank of Canada Working Paper 2010-3.

Patel, R. and Chrisman, J. (2013) 'Risk abatement as a strategy for R\&D investments in family firms', Strategic Management Journal, Vol. 35, No. 4, pp.617-627.

Perotti, E.C. and Gelfer, S. (2001) 'Red barons or robber barons?', European Economic Review, Vol. 45, No. 9, pp.1601-1617.

Ratten, V., Dana, L.P. and Ramadani, V. (2017) 'Internationalisation of family business groups in transition economies', International Journal of Entrepreneurship and Small Business, Vol. 30, No. 4, pp.509-525.

Schmid, T., Achleitner, A.K., Ampenberger, M. and Kaserer, C. (2014) 'Family firms and R\&D behavior - new evidence from a large-scale survey', Research Policy, Vol. 43, No. 1, pp.233-244.

Shleifer, A. and Vishny, R.W. (1986) 'Large shareholders and corporate control', Journal of Political Economy, Vol. 94, No. 3, pp.461-488.

Shyu, J. (2013) 'Ownership structure, capital structure, and performance of group affiliation: evidence from Taiwanese group-affiliated firms', Managerial Finance, Vol. 39, No. 4, pp.404-420.

Villalonga, B. and Amit, R. (2006) 'How do family ownership, control and management affect firm value?', Journal of Financial Economics, Vol. 80, No. 2, pp.385-417. 
Zaddem, F. (2007) 'Leviers et contraintes de la succession au sein d'une entreprise familiale tunisienne', Chapter 5 of the collective work, L'Entrepreneuriat, Théorie, Acteurs et Pratiques, pp.131-65, under the direction of Pr. Riadh Zghal.

Zahra, S.A. (2005) 'Entrepreneurial risk-taking in family firms', Family Business Review, Vol. 18, No. 1, pp.23-39.

\section{Notes}

1 In our sample, we have incorporated all firms making public offerings for which data are available during the period 1998-2014.

2 Family controlled firms are those in which the ownership stake of the controlling shareholder and his family exceeds $5 \%$ and where a member of the family is CEO or president or chairman or vice-president or either a board member (Choi et al., 2015).

3 In the case of our panel regressions, we calculate risk variables for each of the following periods: 1998-2001; 1999-2002; 2000-2003; 2001-2004; 2002-2005; 2003-2006; 20042007; 2005-2008; 2006-2009; 2007-2010; 2008-2011; 2009-2012; 2010-2013; 2011-2014.

4 The Tunisian company law allows firms to track the monist structure (with a unitary board) or the dual structure (with a supervisory board and an executive board).

5 Although we collected data from 1998 to 2014, the last period considered in the regression is 2011 since we calculate risk-taking by earnings volatility over four-year overlapping periods.

\section{Appendix A}

\section{Classification of industries according to the NIS}

1 agriculture, hunt and forestry

2 fishing and fish farming

3 extractive industries

4 agricultural and food industry

5 textile and clothing industry

6 leather industry

7 manufacturing wood products

8 paper and cardboard industry

9 chemical industry

10 rubber and plastics industry

11 metallurgy

12 manufacture of other non-metallic mineral products

13 manufacturing machinery and equipment

14 manufacturing of electrical and electronic equipment

15 manufacturing of transportation equipment 
16 other manufacturing

17 construction, materials and civil engineering

18 trade and car repair

19 wholesale

20 retail business

21 tourism, hotels and restaurants

22 transportation

23 telecommunication

24 new technologies

25 real estate

26 education, health and social actions

27 community, social and personal

28 financial activity

29 media

30 other activities.

\section{Appendix B}

Table 1 Variables definition

\begin{tabular}{|c|c|c|}
\hline Variables & Abbreviation & Definition \\
\hline \multirow[t]{5}{*}{ Risk-taking } & Risk & $\sqrt{\frac{1}{T-1} \sum_{t=1}^{T}\left(E_{i t}-\frac{1}{T} \sum E_{i t}\right)^{2}} / T=4$ \\
\hline & Risk1 & where $E_{i t}=\frac{E B I T D A}{\text { Total Assets }}$ \\
\hline & Risk2 & where $E_{i t}=\frac{E B I T}{\text { Total Assets }}$ \\
\hline & Risk3 & where $E_{i t}=\frac{\text { EBITDA }}{\text { Sales }}$ \\
\hline & Risk4 & where $E_{i t}=\frac{E B I T}{\text { Sales }}$ \\
\hline \multirow[t]{2}{*}{ Family ownership } & Family & Ownership stake belonging to family members \\
\hline & D-family & $\begin{array}{l}\text { A dummy variable that equals one if the ownership } \\
\text { stake belonging to family members exceeds } 5 \% \text { and } \\
\text { zero otherwise }\end{array}$ \\
\hline
\end{tabular}


Table 1 Variables definition (continued)

\begin{tabular}{|c|c|c|}
\hline Variables & Abbreviation & Definition \\
\hline \multirow[t]{3}{*}{ Group affiliation } & Group & $\begin{array}{l}\text { A dummy variable that equals one if the firm is a } \\
\text { member of a business group and zero otherwise }\end{array}$ \\
\hline & $\mathrm{Nb}-\mathrm{FG}$ & $\begin{array}{c}\text { The natural logarithm of the number of firms in the } \\
\text { group }\end{array}$ \\
\hline & $\mathrm{Nb}-\mathrm{IG}$ & $\begin{array}{l}\text { The natural logarithm of the number of industries } \\
\text { in which the group operates }\end{array}$ \\
\hline \multirow[t]{7}{*}{$\begin{array}{l}\text { Family firm } \\
\text { characteristics }\end{array}$} & Fam.manag & $\begin{array}{l}\text { A dummy variable that equals one if the CEO or } \\
\text { the executive officer is a member of the family and } \\
\text { zero otherwise }\end{array}$ \\
\hline & Found.manag & $\begin{array}{c}\text { A dummy variable that equals one if the CEO or } \\
\text { the executive officer is the founder and zero } \\
\text { otherwise }\end{array}$ \\
\hline & Latergen.manag & $\begin{array}{l}\text { A dummy variable that equals one if a descendant } \\
\text { of the founder is the CEO or the executive officer } \\
\text { and zero otherwise }\end{array}$ \\
\hline & Found.sup & $\begin{array}{c}\text { A dummy variable that equals one if the founder is } \\
\text { the chairman of the board of directors and zero } \\
\text { otherwise }\end{array}$ \\
\hline & Latergen.sup & $\begin{array}{l}\text { A dummy variable that equals one if the chairman } \\
\text { of the board of directors is one of the descendants } \\
\text { of the founder and zero otherwise }\end{array}$ \\
\hline & Succession & $\begin{array}{l}\text { A dummy variable that equals one if there has been } \\
\text { a succession of the ownership to the descendants of } \\
\text { the founder }\end{array}$ \\
\hline & No.Fam.Manag & $\begin{array}{l}\text { A dummy variable that equals one if the firm is } \\
\text { managed by a non-member of the family and zero } \\
\text { otherwise }\end{array}$ \\
\hline \multirow[t]{2}{*}{ Firm size } & Lnassets & The natural logarithm of total asset. \\
\hline & Lnsales & The natural logarithm of total sales \\
\hline Leverage & Leverage & $\frac{\text { Total liabilities }}{\text { Total Assets }}$ \\
\hline Firm profitability & Profitability & $\frac{\text { EBITDA }}{\text { Assets }} \frac{\text { EBITDA }}{\text { Sales }}$ \\
\hline Firm age & Age & $\begin{array}{l}\text { The natural logarithm of the number of years since } \\
\text { firm's incorporation }\end{array}$ \\
\hline Sales growth & Salesgrowth & $\frac{\text { Firm Sales }_{t}-\text { Firm Sales }_{t-1}}{\text { Firm Sales }_{t-1}}$ \\
\hline Tangible assets & Tangible & $\frac{\text { Tangible assets }}{\text { Total assets }}$ \\
\hline Foreigners' ownership & Foreigners & Ownership stake belonging to foreigners \\
\hline $\begin{array}{l}\text { Financial institutions' } \\
\text { ownership }\end{array}$ & Institutions & Ownership stake belonging to financial institutions \\
\hline
\end{tabular}

